\title{
Effects of Treatment with Electrolyzed Oxidizing Water on Postharvest Diseases of Avocado
}

\author{
Md Kamrul Hassan 1,2 and Elizabeth Dann 1,*(D) \\ 1 Centre for Horticultural Science, Queensland Alliance for Agriculture and Food Innovation, \\ The University of Queensland, 2CW Ecosciences Precinct, Dutton Park, Brisbane QLD 4102, Australia; \\ kamrulhassan.hort@bau.edu.bd \\ 2 Department of Horticulture, Faculty of Agriculture, Bangladesh Agricultural University, \\ Mymensingh 2202, Bangladesh \\ * Correspondence: e.dann@uq.edu.au
}

Received: 14 October 2019; Accepted: 29 October 2019; Published: 11 November 2019

\begin{abstract}
The present study comprised five trials to investigate the efficacy of postharvest treatment with electrolyzed oxidizing (EO) water on postharvest disease development in avocado. Mature (dry matter 24-34\%), hard green fruit cv. Hass (four trials), and cv. Wurtz (one trial) from orchards receiving minimal fungicide sprays were sourced, and subsequently dipped for $30 \mathrm{~s}$ in treatment solutions. Fruit were ripened at $23{ }^{\circ} \mathrm{C}$ and $65 \%$ relative humidity to encourage postharvest disease development, and assessed when ripe for anthracnose and stem end rot (SER), arising from natural field infections and/or the size of lesions resulting from post-treatment inoculation with Colletotrichum siamense. In the case of natural infection, EO water treatment reduced severity of SER disease by 30-75\% compared with water treated control fruit in all four trials where it was assessed. Reduction in severity of SER after Graduate A+ fungicide or hypochlorite $(\mathrm{NaOCl})$ bleach treatment ranged from $60-88 \%$ or $25-50 \%$, respectively, compared with water controls. Under extremely high anthracnose disease pressure, $20 \% v / v$ EO water, $\mathrm{NaOCl}$, as well as Graduate A+ fungicide treatments were mostly ineffective. Treatments in the final trial were applied as overhead sprays in an experimental-scale packing line to simulate commercial conditions. This was the only trial where anthracnose (as well as SER) was significantly reduced in fruit by $20 \% v / v$ EO water (12-35\%) and Graduate A+ (34\%) compared with water control. In two trials with C. siamense-inoculated fruit, anthracnose lesion size was reduced by $68-85 \%$, and $90-100 \%$ by $20 \% v / v$ EO water and Graduate $\mathrm{A}+$, respectively, compared with water-treated fruit. Fruit firmness and the number of days to ripen were mostly not affected by the treatments. This study demonstrates the potential for electrolyzed oxidizing water to be incorporated into integrated management programs for postharvest diseases of avocado, and possibly other fresh produce.
\end{abstract}

Keywords: anolyte; Graduate A+; prochloraz; sodium hypochlorite; anthracnose; stem end rot

\section{Introduction}

Anthracnose (caused primarily by Colletotrichum spp.) and stem end rot (caused by Colletotrichum spp., Botryosphaeriaceae fungi and others) are considered the most serious postharvest diseases of avocado fruit that result in considerable losses during storage and marketing [1,2]. Generally, synthetic fungicides such as Sportak (450 $\mathrm{g} \mathrm{L}^{-1}$ prochloraz) and Graduate $\mathrm{A}+\left(200 \mathrm{~g} \mathrm{~L}^{-1}\right.$ azoxystrobin and $200 \mathrm{~g} \mathrm{~L}^{-1}$ fludioxonil), are used in packing lines to reduce losses caused by postharvest diseases, and follow a field fungicide program [3,4]. Markets are becoming increasingly sensitive to pesticides applied to food through growing cycles and after harvesting, and maximum residue limits (MRLs) are becoming stricter, with alternative pest and disease reduction measures being sought. 
In addition to the application of synthetic fungicides, different types of chlorine-based sanitizers are used in harvested fruit and vegetables to reduce microbial load prior to packaging. Liquid chlorine, hypochlorite, inorganic and organic chloramines, chlorine dioxide, and hypochlorous acid are common chlorine-based sanitizers. In practice, chlorine-based sanitizers are produced as highly concentrated and corrosive chemical solutions, which are diluted before use, and therefore introduce workers' health and safety issues during storage and application $[5,6]$.

Electrolyzed oxidizing (EO) water (also known as electro-activated water or ionized water solution) has been reported to be highly microbiocidal against bacteria, viruses, fungi, and protozoa and may represent an alternative to synthetic chemicals and traditional chlorine-based sanitizers [5,7-9]. EO water is generated by electrolysis of a dilute salt $(\mathrm{NaCl})$ solution in an electrolysis chamber where anode and cathode are separated by a membrane or diaphragm and two types of electrolyzed water are generated simultaneously. At the anode, acidic electrolyzed water with a $\mathrm{pH}$ of 2-3 and oxidation-reduction potential (ORP) $>1100 \mathrm{mV}$ is produced, whereas at the cathode, basic electrolyzed water with a $\mathrm{pH}$ of 10-13 and ORP of 800 to $900 \mathrm{mV}$ is produced. Neutral electrolyzed water with a $\mathrm{pH}$ of 7-8 and ORP of 750-900 $\mathrm{mV}$ is produced by mixing the anodic solution with $\mathrm{OH}^{-}$ions or by using a single-cell unit without diaphragm $[6,10,11]$.

EO water exerts its antimicrobial effects due to its high ORP and concentration of available chlorine species such as hypochlorous acid and hypochlorite ions [12,13], and their respective levels determine the efficacy of EO water and other chlorine-based solutions as sanitizers [14-16]. It is now common for postharvest processors to monitor ORP (in $\mathrm{mV}$ ) as well as chlorine dose (in ppm) as both parameters contribute to antimicrobial potential [17]. An oxidizing solution with high ORP takes electrons away from microbial cell membranes, causing collapse of the cell [17]. Solutions with higher ORP possess greater oxidizing strength compared to solutions with weak ORP [16]. EO water with high ORP, that is, $800-1000 \mathrm{mV}$ may be considered as an effective sanitizer against microorganisms. Active chlorine content (ACC) refers to the amounts of active chlorine such as chlorine gas $\left(\mathrm{Cl}_{2}\right)$, hypochlorous acid $(\mathrm{HOCl})$, and hypochlorite ions $\left(\mathrm{OCl}^{-}\right)$present in solution. Both $\mathrm{HOCl}$ and $\mathrm{ClO}^{-}$inactivate pathogenic and spoilage bacteria through oxidative damage to cell membranes [18]. $\mathrm{pH}$ determines the available forms and concentrations of $\mathrm{ACC}$ in $\mathrm{EO}$ water solution, and $\mathrm{OCl}^{-}, \mathrm{HOCl}$, and $\mathrm{Cl}_{2}$ are the predominant forms at high, neutral, and low $\mathrm{pH}$, respectively $[7,9,19]$. Commercial bleach such as calcium or sodium hypochlorites have $\mathrm{OCl}^{-}$ions, whereas the major active antimicrobial and sporicidal agent in neutral $\mathrm{EO}$ water is $\mathrm{HOCl}$, which is the stronger oxidant due to its higher ORP and is 80 times more antimicrobial compared with $\mathrm{OCl}^{-}$[20]. Hypochlorous acid as the dominant species in water is more desirable than hypochlorite ions for effective disinfection and oxidation due to its higher standard electrode potential, or electromotive force, driving the reduction half-reaction [19].

EO water in neutralized form has low corrosion potential and is reasonably stable in pure form. EO water can evaporate or become deactivated when it reacts with organic matter, and can be diluted with tap water, or removed by reverse osmosis [21]. EO water has low chemical impacts on the environment because it uses only low levels of salt solution with no other added chemical compounds [12]. Furthermore, as it can be produced on-site, there is a reduced risk of chemical exposure to skin during transport, storage, and handling as compared to the concentrated bleach compounds [22].

A previous study evaluated anthracnose and stem end rot of avocado after dip treatment in chlorine-based or quaternary ammonia sanitisers [23]. A three-fold commercial concentration (900 ppm) of the chlorine test solution reduced anthracnose compared with water dip control; however, stem end rot was increased [23]. Although there are no reports relating to the effectiveness of EO water to reduce postharvest diseases in avocado, there are a few studies demonstrating that field applications or postharvest treatment reduced development of disease and improved shelf life in some plants and harvested fresh produce. For example, EO water was found to be effective in the management of infection of Botrytis cinerea on strawberry plants in the field where application of $100 \mathrm{ppm}$ EO water twice per week was more effective than a once per week fungicide (Captan) application [24]. 
Fujiwara et al. [25] reported that the severity of powdery mildew infection on cucumber leaves was reduced by successive sprays of $\mathrm{EO}$ and electrolyzed reducing water.

EO water disinfestation is already in use in a diverse array of food processing plants in Australia [26]. It has been easily implemented into existing packing line infrastructure and has a low on-going cost after initial installation of generating equipment $[8,10,21,27,28]$. Because there are few reports on the reduction of postharvest diseases of fruit using $\mathrm{EO}$ water, the present study was undertaken to examine the efficacy of treating avocado fruit with EO water on the severity of postharvest diseases and shelf life, compared with industry standard fungicides and a common chlorine-based sanitizer.

\section{Materials and Methods}

\subsection{Trials Conducted}

Table 1 summarizes the treatments and replication included in each of the five trials, which were conducted between April and September 2018. Mature hard avocado fruit of uniform size and shape and free from visible disease symptoms were sourced from a non-sprayed orchard in northern New South Wales (trials with cv. Hass) or from an orchard near Bundaberg of Queensland, which received copper sprays throughout the season but had not received pre-harvest azoxystrobin fungicide spray (trial with cv. Wurtz). Fruits were transported to the laboratory facilities at Ecosciences Precinct, Dutton Park, Queensland (Trials 1-4) or Maroochy Research Station, Nambour, Queensland (Trial 5). Dry matter contents of the experimental avocados for all the trials were determined by drying cores of flesh at $45{ }^{\circ} \mathrm{C}$ for $2-3$ days, and were between $24 \%$ and $34 \%$. All batches of fruit had exceeded the minimum commercial maturity standard set by the Australian industry ( $23 \%$ for Hass).

Experimental fruit were dipped in treatment solutions in their replicate batches for $30 \mathrm{~s}$ except for Trial 5 (Table 1), dried at ambient temperature, and re-packed into avocado trays. Trial 1 examined the effects of various concentrations of electrolyzed oxidizing (EO) water and industry standard fungicides (Sportak and Graduate A+) on postharvest diseases of avocado resulting from natural field infection. Trial 2 was similar to Trial 1 but only anthracnose disease arising from inoculation with Colletotrichum siamense was assessed. Trials 3 and 4 were repeat experiments with cultivars Wurtz and Hass that examined the effects of EO water, fungicide, and commercial bleach (sodium hypochlorite) on postharvest diseases arising from both natural infections and inoculation. Trial 5 was undertaken to confirm the results of previous trials and evaluated EO water and Graduate A+ fungicide in an experimental-scale sprayline. The treated fruit from all the trials were maintained in a controlled environment ripening room at $22-23{ }^{\circ} \mathrm{C}$ and $65-70 \%$ relative humidity to optimize expression of postharvest diseases. All the trials were laid out in completely randomized designs (CRD).

\subsection{Application of Postharvest Treatments}

Electrolyzed oxidizing (EO) water was provided for testing by Mr. Mark Parkinson, Lockyer Agronomics, Gatton, Queensland, facilitated by Mr. Keith Mason, Envirolyte Australia. EO water solutions of desired concentrations were prepared by mixing EO water of $100 \% v / v$ with tap water. Concentrations of EO water for testing were determined on the basis of previous reports. Different concentrations were tested in Trials 1 and 2, and in subsequent trials $20 \% v / v$ was selected as $10 \%, 20 \%$, and $30 \% v / v$ EO water produced statistically similar results.

Graduate A+ (active ingredients $200 \mathrm{~g} \mathrm{~L}^{-1}$ azoxystrobin and $200 \mathrm{~g} \mathrm{~L}^{-1}$ fludioxonil) was sourced from Syngenta Crop Protection Pty Ltd., 2-4 Lyon Park Road, NSW 2112, Australia. The registered label rate of Graduate A+ was prepared by mixing Graduate A+ at $2.5 \mathrm{~mL} \mathrm{~L}^{-1}$. Sportak $\left(450 \mathrm{~g} \mathrm{~L}^{-1}\right.$ prochloraz as active constituent) obtained from FMC Australasia Pty Ltd., was prepared at the label rate of $0.55 \mathrm{~mL} \mathrm{~L}^{-1}$. 
Table 1. Summary of trials undertaken with harvested avocado fruit.

\begin{tabular}{|c|c|c|c|c|c|c|c|c|c|c|c|c|c|c|}
\hline \multirow[t]{2}{*}{ Trial } & \multirow[t]{2}{*}{ Cv. } & \multirow{2}{*}{$\begin{array}{l}\text { Natural } \\
\text { Infection }\end{array}$} & \multirow{2}{*}{ Inocu-lation } & \multicolumn{2}{|c|}{ Electrolyzed } & \multicolumn{2}{|c|}{ xidizing (EO } & \multicolumn{2}{|c|}{ Vater $(\% v / v)$} & \multirow[t]{2}{*}{$\begin{array}{c}\mathrm{NaOCl} \\
100 \text { ppm }\end{array}$} & \multicolumn{2}{|c|}{ Fungicides } & \multicolumn{2}{|c|}{ Treatment Time } \\
\hline & & & & 0 & 1 & 5 & 10 & 20 & 30 & & Graduate A+ & Sportak & $30 \mathrm{~s}$ & $60 \mathrm{~s}$ \\
\hline 1 & Hass & $\bullet$ & & $\bullet$ & $\bullet$ & $\bullet$ & $\bullet$ & & & & $\bullet$ & $\bullet$ & $\bullet$ & \\
\hline 2 & Hass & & $\bullet$ & $\bullet$ & & & - & $\bullet$ & $\bullet$ & & 0 & & $\bullet$ & \\
\hline 3 & Wurtz & $\bullet$ & - & $\bullet$ & & & & $\bullet$ & & $\bullet$ & - & & $\bullet$ & \\
\hline 4 & Hass & - & - & • & & & & - & & - & - & & - & \\
\hline 5 & Hass & • & & • & & & & • & & & - & & • & • \\
\hline
\end{tabular}

Trial 1: Six treatments (control- water; EO water $1 \% v / v$; EO water $5 \% v / v$; EO water $10 \% v / v$; Graduate A+ $2.5 \mathrm{~mL} \mathrm{~L}^{-1}$; and Sportak $0.55 \mathrm{~mL} \mathrm{~L}^{-1}$ ) and four replicates of 10 fruit per replicate; Trial 2: Five treatments (control-water; EO water $10 \% v / v$; EO water $20 \% v / v$; EO water $30 \% v / v$; and Graduate A+ $2.5 \mathrm{~mL} \mathrm{~L}^{-1}$ ) and four replicates of 10 fruit per replicate; Trials 3 and 4 : Four treatments (control-water; EO water $20 \% v / v$; sodium hypochlorite $100 \mathrm{ppm}$; and Graduate A+ $2.5 \mathrm{~mL} \mathrm{~L}^{-1}$ ) and four replicates of 15 fruit per replicate (5 fruit for inoculation and 10 fruits for natural infection); Trial 5: Five treatments (control- water for 30 and $60 \mathrm{~s}$; EO water $20 \% v / v$ for 30 and $60 \mathrm{~s}$; Graduate A+2.5 $\mathrm{mL} \mathrm{L}^{-1}$ for $30 \mathrm{~s}$ ) and five replicates of 20 fruit per replicate. 
Sodium hypochlorite ( $\mathrm{NaOCl}), 100 \mathrm{mg} \mathrm{L}^{-1}$, was prepared from commercial bleach of $125 \mathrm{~g} \mathrm{~L}^{-1}$ active constituent as sodium hypochlorite (HY-CLOR Australia Pty Limited, New South Wales). A total of $8 \mathrm{~mL}$ of concentrated bleach was added to $10 \mathrm{~L}$ of water in a plastic bucket.

For Trials 1-4, adequate quantities of each treatment solution (5-10 L) were prepared in plastic buckets, and fruit were dipped for $30 \mathrm{~s}$ then allowed to air-dry on racks. Fruit were then repacked in the avocado trays and maintained in the controlled environment room as described previously. However, for Trial 5, fruit were rotated on rollers while pre-washed with tap water from overhead spray (to waste) for approximately 10-15 s. Fruit were then advanced to rotation by brushes, and treatment solutions were applied by recirculating overhead spray from a $200 \mathrm{~L}$ tank for 30 or $60 \mathrm{~s}$. The treated fruit were allowed to air dry, packed in avocado trays, and were transported to Ecosciences Precinct, Dutton Park, Brisbane, and held in a controlled environment room for observation.

\subsection{Measurement of $p H$, Oxidation Reduction Potential (ORP), and Free Chlorine in Treatment Solutions}

Oxidation reduction potential (ORP), $\mathrm{pH}$, and free chlorine (hypochlorite, $\mathrm{ClO}^{-}$) of the prepared EO water solutions in Trials $2-5$ were measured. Samples of approximately $100 \mathrm{~mL}$ were taken in triplicate from the test solutions. $\mathrm{pH}$ and ORP were measured immediately after preparation of the solutions, and free chlorine was measured within $72 \mathrm{~h}$ of preparation.

The oxidation reduction potential of the EO water solutions and the control (tap water) were determined using an ORP meter (Milwaukee 500 ORP Meter). The electrode of the ORP meter was inserted into the solutions and measurements were taken when the reading stabilized. $\mathrm{pH}$ was measured in $20 \mathrm{~mL}$ samples using a standard laboratory $\mathrm{pH}$ meter (Met Rohm, PC).

Free chlorine is the sum of hypochlorous acid $(\mathrm{HOCl})$ and hypochlorite ion $\left(\mathrm{ClO}^{-}\right)$. In the present study the concentration of $\mathrm{ClO}^{-}$in the treatment solutions was determined by redox titration as per the method described by Dr. Richard Walding, Griffith University, Australia (downloaded from: http: //seniorchem.com/chlorine_thiosulfate_titration.pdf). This method involves converting the hypochlorite ion $\left(\mathrm{ClO}^{-}\right)$of bleach solution to iodine $\left(\mathrm{I}_{2}\right)$ by the addition of $\mathrm{KI}$ and then titrating resultant iodine with thiosulfate $\left(\mathrm{S}_{2} \mathrm{O}_{3}{ }^{2-}\right)$ solution, which can be visualized by the change from brown to slight yellow color. As this end-point is difficult to detect, starch indicator is added, forming a blue complex with iodine. As the iodine reacts with thiosulfate, the blue color disappears, indicating the reaction end-point. The titre value was then used for calculation of concentration of the free chlorine $\left(\mathrm{as}^{-\mathrm{Cl}^{-}}\right)$in the treatment solutions, given that 1 mole of $\mathrm{ClO}^{-}$is equivalent to 2 moles of $\mathrm{S}_{2} \mathrm{O}_{3}{ }^{2-}$. The concentration of hypochlorite ions was then calculated using the formula: $\mathrm{C}$ (hypochlorite) $\times \mathrm{V}$ (hypochlorite) $=\mathrm{C}$ (thiosulfate) $\times \mathrm{V}$ (thiosulfate) $/ 2$. The concentration is expressed in ppm $\left(\mathrm{mg} \mathrm{L}^{-1}\right)$ using the formula, $\mathrm{C}\left(\mathrm{ClO}^{-}\right)=\mathrm{C}\left(\mathrm{ClO}^{-}\right) \times \mathrm{M}\left(\mathrm{ClO}^{-}\right)$, where $\mathrm{M}\left(\mathrm{ClO}^{-}\right)$is the molecular mass of hypochlorite $\left(51.5 \mathrm{~g} \mathrm{~mol}^{-1}\right)$.

\subsection{Fruit Inoculation}

Apart from the assessment of postharvest diseases arising from natural field infections (Trials 1, 3,4 , and 5), fruit were also inoculated (Trials 2, 3, and 4) to determine efficacy of treatments when applied prior to pathogen infection. One day after dipping in chlorine-based or fungicide solutions, fruit were removed from the trays and placed on racks within plastic boxes $(20 \times 12 \times 6 \mathrm{~cm})$, which had been lined with moistened paper towels to create a humid environment. Circles approximately $1.0-1.5 \mathrm{~cm}$ diameter were drawn on two positions on each fruit to indicate sites for inoculation. A $20 \mu \mathrm{L}$ droplet of conidial suspension $\left(10^{6}\right.$ conidia $\left.\mathrm{mL}^{-1}\right)$ of Colletotrichum siamense (originally isolated from avocado, BRIP 63702) was placed within the circles (Figure 1A). The boxes were sealed to maintain high humidity for $24 \mathrm{~h}$ to facilitate spore germination and infection of fruit. After the incubation period, fruit were removed and placed back into their avocado trays within the ripening room. 

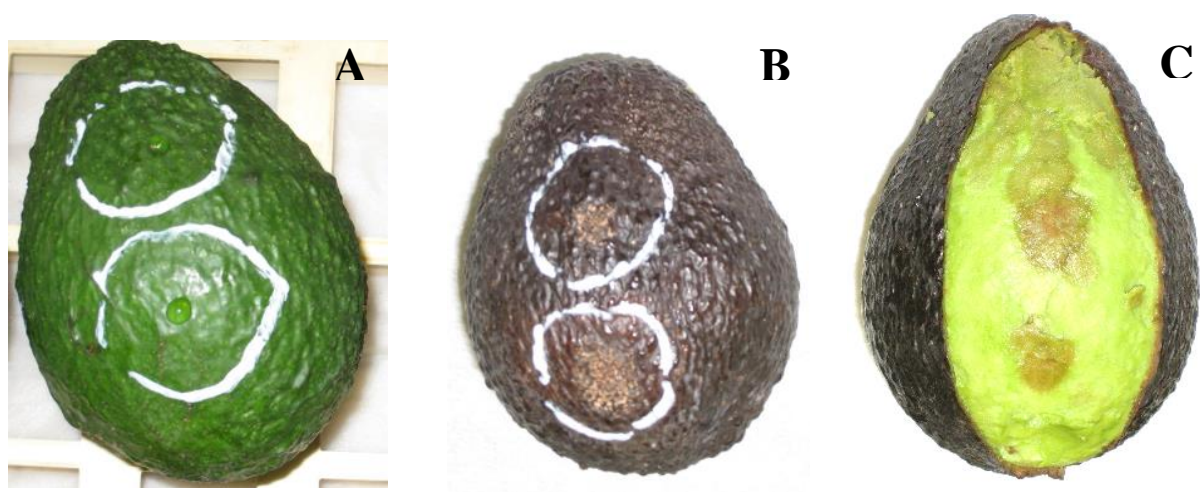

Figure 1. Avocado fruits (cv. Hass) immediately after inoculation (A), and external (B) and internal (C) anthracnose symptoms in control fruits at eating ripe stage.

\subsection{Fruit Assessment}

Softness (mm deformation) of fruit was assessed at eating ripe stage using non-destructive fruit firmness tester [29]. A $500 \mathrm{~g}$ weight was applied to each of the fruit and the deformation was recorded in $\mathrm{mm}$ after $30 \mathrm{~s}$.

Fruit were checked daily for ripening and when deemed "eating ripe" (as determined by hand pressure test and color) each piece was removed from the ripening room and assessed for severity of postharvest disease arising from natural field infection. Hass fruit peel becomes dark purple/black upon ripening, thus peeling is necessary in order to see and quantify the progression of postharvest disease. The percentage of fruit surface area affected by side rots (mostly anthracnose) was determined by visual assessment. Stem end rot (percent fruit volume affected) was determined by visual estimation after slicing fruit transversely and rating for internal disease severity arising from the stem. Incidence (percent numbers of fruit affected) of anthracnose and stem end rot was also determined. Fruit that were inoculated were peeled, and the diameters of lesions at the inoculation point were measured (two perpendicular measurements per lesion). The lesion was assumed circular and the area was calculated by using the formula $\pi r^{2}$. The number of days from harvest to eating ripe was determined for each treatment. Incidence and severity of anthracnose and stem end rot for the variety Wurtz were determined on the basis of external symptoms without peeling as the fruit remain green when ripe.

\subsection{Data Analysis}

Data were analyzed using IBM SPSS Statistics (Version 25). For percentage data, arcsine transformations were carried out to satisfy assumption of ANOVA and analysis was performed on the transformed data. Mean separations were performed according to least significant difference (LSD) test post hoc only where significant treatment effects were found.

\section{Results}

Five trials were conducted to determine the effects of $\mathrm{EO}$ water on postharvest anthracnose and stem end rot diseases of avocado. Fruit in Trials 1-4 were dipped in treatment solutions, whereas in Trial 5, an experimental packing line was utilized where fruit were rolled on brushes and treatments applied by recirculating overhead sprays.

\subsection{Trial 1}

There were significant effects of postharvest treatments on anthracnose incidence $(p<0.01)$ and severity $(p<0.01)$ (Table 2$)$. In terms of incidence, there were significantly fewer fruit with anthracnose from the Graduate A+ fungicide treatment compared with all other treatments. Fruit dipped in 5 or $10 \% v / v$ EO water had significantly more fruit with anthracnose compared with water or Sportak treated controls. Anthracnose severity was significantly lower in fruit from Graduate A+ and Sportak 
fungicide treatments compared with all other treatments (Table 2). There were no significant differences in stem end rot (SER) incidence amongst treatments. However, severity of SER in fruit from 5\% to $10 \% v / v$ EO water, Graduate A+, and Sportak was similar and significantly less than in water treated control fruit (Table 2).

The number of days to reach eating ripe stage was not significantly affected by postharvest treatments (Table 2). However, fruit softness differed significantly $(p<0.01$; Table 2$)$, with fruit dipped in Graduate A+ fungicide significantly softer (more deformation under pressure) compared with fruit dipped in all other treatments except Sportak. The EO water-treated fruit and those dipped in water had the same levels of softness at eating ripe stage.

Table 2. Effect of electrolyzed oxidizing (EO) water and synthetic fungicides on postharvest diseases and ripening properties of avocado cv. Hass, Trial 1.

\begin{tabular}{ccccccc}
\hline \multirow{2}{*}{ Postharvest Treatments } & \multicolumn{2}{c}{ Anthracnose (\%) } & \multicolumn{2}{c}{ Stem End Rot (\%) } & Days to Eating & \multirow{2}{*}{ Softness } \\
\cline { 2 - 4 } & Incidence & Severity & Incidence & Severity & & \\
\hline Control (water) & $70.0 \mathrm{~b}$ & $62.0 \mathrm{a}$ & 66.7 & $28.3 \mathrm{a}$ & 18.3 & $1.6 \mathrm{bc}$ \\
EO water $(1 \% v / v)$ & $80.0 \mathrm{ab}$ & $55.8 \mathrm{a}$ & 60.0 & $20.7 \mathrm{ab}$ & 17.8 & $1.5 \mathrm{c}$ \\
EO water $(5 \% \mathrm{v} / \mathrm{v})$ & $90.0 \mathrm{a}$ & $53.3 \mathrm{a}$ & 50.0 & $12.6 \mathrm{~b}$ & 18.2 & $1.6 \mathrm{bc}$ \\
EO water $(10 \% v / v)$ & $90.0 \mathrm{a}$ & $50.2 \mathrm{a}$ & 66.7 & $15.9 \mathrm{~b}$ & 18.8 & $1.6 \mathrm{c}$ \\
Graduate A+ $\left(2.5 \mathrm{~mL} \mathrm{~L}^{-1}\right)$ & $50.0 \mathrm{c}$ & $15.0 \mathrm{~b}$ & 50.0 & $11.5 \mathrm{~b}$ & 18.8 & $1.8 \mathrm{a}$ \\
Sportak $\left(0.55 \mathrm{~mL} \mathrm{~L}^{-1}\right)$ & $70.0 \mathrm{~b}$ & $21.8 \mathrm{~b}$ & 40.0 & $10.3 \mathrm{~b}$ & 18.4 & $1.7 \mathrm{ab}$ \\
\hline
\end{tabular}

Within each column, means followed by the same letter do not differ significantly at the $5 \%$ level of probability according to LSD post hoc test. $n=4$ replicates of 10 fruit per replicate. $\uparrow$ indicates $\mathrm{mm}$ deformation upon $500 \mathrm{~g}$ weight applied on fruit at eating ripe stage for $30 \mathrm{~s}$.

\subsection{Trial 2}

This trial included two EO water treatments at higher concentrations, $20 \%$ and $30 \% v / v$, and fruit were inoculated with one of the anthracnose-causing pathogens, Colletotrichum siamense, and lesion area was determined at eating ripe stage.

The postharvest treatments resulted in significant differences $(p<0.01)$ in anthracnose lesion size after inoculation with $C$. siamense (Table 3, Figure 1). Lesions were significantly smaller in fruit that had been dipped in any concentration of EO water or the fungicide Graduate A+, compared with water control (Table 3). There were no significant differences in the number of days to reach eating ripe or fruit softness amongst treatments. EO water of $10 \%, 20 \%$, and $30 \% v / v$ concentrations produced statistically identical results in terms of anthracnose lesions produced through inoculation with C. siamense, and intermediate concentration of $20 \%(v / v)$ was selected for the next trials.

Table 3. Effect of electrolyzed oxidizing (EO) water and synthetic fungicide on anthracnose lesion area and ripening properties of avocado (cv. Hass) after inoculation with Colletotrichum siamense, Trial 2.

\begin{tabular}{cccc}
\hline Postharvest Treatments & Lesion Area $\left(\mathbf{m m}^{\mathbf{2}}\right)$ & Days to Eating Ripe Stage & Softness \\
\hline Control $($ water $)$ & $75.2 \mathrm{a}$ & 18.0 & 1.6 \\
EO water $(10 \% v / v)$ & $10.5 \mathrm{bc}$ & 17.5 & 1.6 \\
EO water $(20 \% v / v)$ & $24.2 \mathrm{bc}$ & 18.2 & 1.7 \\
EO water $(30 \% v / v)$ & $39.7 \mathrm{~b}$ & 17.5 & 1.6 \\
Graduate A+ $\left(2.5 \mathrm{~mL} \mathrm{~L}^{-1}\right)$ & $7.60 \mathrm{c}$ & 18.6 & 1.6 \\
\hline
\end{tabular}

Within each column, means followed by the same letter do not differ significantly at the $5 \%$ level of probability according to LSD post hoc test. $n=4$ replicates of 10 fruit per replicate. $\uparrow$ indicates $\mathrm{mm}$ deformation upon $500 \mathrm{~g}$ weight applied on fruit at eating ripe stage for $30 \mathrm{~s}$.

\subsection{Trial 3}

This trial with avocado variety Wurtz examined the efficacy of EO, a commonly-used sanitizer, sodium hypochlorite $(\mathrm{NaOCl})$, and Graduate $\mathrm{A}+$ on severity of postharvest diseases. The variety 
Wurtz was selected to clearly observe anthracnose lesions externally after inoculation because skin of this variety remains green upon ripening. Dipping fruit in $\mathrm{EO}$ water $(20 \% v / v), \mathrm{NaOCl}$, or the fungicide Graduate A+ $24 \mathrm{~h}$ prior to inoculation with $C$. siamense, significantly $(p<0.01)$ reduced anthracnose lesion size compared with water-treated controls (Table 4); in fact, there were no lesions on fruit treated with Graduate A+. Fruit softness differed significantly $(p<0.01)$ amongst treatments, where fruit treated with $\mathrm{NaOCl}$ and $\mathrm{EO}$ water were significantly less soft than those dipped in Graduate $\mathrm{A}+$. Time to reach eating ripe stage also varied significantly $(p<0.01)$ and the control fruit took less time to ripen than fruit from all other treatments. $\mathrm{EO}$ water and $\mathrm{NaOCl}$ had statistically identical effects on the number of days to ripen.

Table 4. Effect of electrolyzed oxidizing (EO) water and synthetic fungicide on anthracnose lesion area and ripening properties of avocado (cv. Wurtz) after inoculation with Colletotrichum siamense, Trial 3.

\begin{tabular}{cccc}
\hline Postharvest Treatments & $\begin{array}{c}\text { Anthracnose Lesion } \\
\text { Areas }\left(\mathbf{m m}^{\mathbf{2}}\right)\end{array}$ & $\begin{array}{c}\text { Days to Reach Eating } \\
\text { Ripe Stage }\end{array}$ & Softness \\
\hline Control (water) & $74.5 \mathrm{a}$ & $10.0 \mathrm{c}$ & $1.8 \mathrm{ab}$ \\
$\mathrm{EO} \mathrm{water}(20 \% \mathrm{v} / \mathrm{v})$ & $10.5 \mathrm{~b}$ & $11.6 \mathrm{ab}$ & $1.7 \mathrm{bc}$ \\
$\mathrm{NaOCl}\left(100 \mathrm{mg} \mathrm{L}^{-1}\right)$ & $6.3 \mathrm{~b}$ & $12.6 \mathrm{a}$ & $1.5 \mathrm{c}$ \\
Graduate $\mathrm{A}+\left(2.5 \mathrm{~mL} \mathrm{~L}^{-1}\right)$ & $0.0 \mathrm{~b}$ & $11.1 \mathrm{~b}$ & $2.0 \mathrm{a}$ \\
\hline
\end{tabular}

Within each column, means followed by the same letter do not differ significantly at the $5 \%$ level of probability according to LSD post hoc test. $n=4$ replicates of 5 fruit per replicate. $\uparrow$ indicates mm deformation upon $500 \mathrm{~g}$ weight applied on fruit for $30 \mathrm{~s}$.

Anthracnose and stem end rot arising from natural infections were also assessed on non-inoculated fruit. Disease incidence and severity were particularly high, and all fruit in each treatment had anthracnose and there were no significant differences in incidence or severity amongst treatments (Table 5). Stem end rot development was also high, and although incidence was not significantly affected by postharvest treatment, there were differences amongst treatments in severity $(p<0.01)$. Stem end rot was least severe in $20 \% v / v$ EO water and Graduate A+ treated fruit, and was significantly lower than in fruit treated with water or $\mathrm{NaOCl}$ (Table 5). Fruit firmness and time to reach eating ripe stage were not significantly affected by postharvest treatments (Table 5).

Table 5. Effect of electrolyzed oxidizing (EO) water and synthetic fungicides on postharvest diseases and ripening properties of avocado cv. Wurtz, Trial 3.

\begin{tabular}{ccccccc}
\hline \multirow{2}{*}{ Postharvest Treatments } & \multicolumn{2}{c}{ Anthracnose (\%) } & \multicolumn{2}{c}{ Stem End Rot (\%) } & Days to & \multirow{2}{*}{ Softness } \\
\cline { 2 - 5 } & Incidence & Severity & Incidence & Severity & Eating Ripe & \\
\hline Control (water) & 100.0 & 69.8 & 76.7 & $40.8 \mathrm{a}$ & 12.5 & 1.7 \\
$\mathrm{EO} \mathrm{water}(20 \% \mathrm{v} / \mathrm{v})$ & 100.0 & 61.5 & 50.0 & $10.3 \mathrm{~b}$ & 12.3 & 1.5 \\
$\mathrm{NaOCl}\left(100 \mathrm{mg} \mathrm{L}^{-1}\right)$ & 100.0 & 69.0 & 73.3 & $31.2 \mathrm{a}$ & 12.6 & 1.6 \\
Graduate $\mathrm{A}+\left(2.5 \mathrm{~mL} \mathrm{~L}^{-1}\right)$ & 100.0 & 59.0 & 40.0 & $6.2 \mathrm{~b}$ & 12.5 & 1.6 \\
\hline
\end{tabular}

Within each column, means followed by the same letter do not differ significantly at the $5 \%$ level of probability according to LSD post hoc test. $n=4$ replicates of 10 fruit per replicate. $\uparrow$ indicates $\mathrm{mm}$ deformation upon $500 \mathrm{~g}$ weight applied on fruit for $30 \mathrm{~s}$.

\subsection{Trial 4}

This trial with avocado variety Hass examined the efficacy of EO water along with commonly-used sanitizer, $\mathrm{NaOCl}$, and Graduate $\mathrm{A}+$ on severity of postharvest diseases. Inoculation of Hass with C. siamense was not as successful as with Wurtz (Trial 3), and lesions were smaller with no significant differences amongst treatments; however, lesions on EO water-dipped fruit were smaller than in water or hypochlorite-treated fruit and no lesions developed on Graduate A+-dipped fruit (Table 6). Fruit firmness and time to reach eating ripe stage were not significantly affected by treatment (Table 6). 
Table 6. Effect of electrolyzed oxidizing (EO) water, synthetic fungicide, and $\mathrm{NaOCl}$ on anthracnose lesion area and ripening properties of avocado (cv. Hass) after inoculation with Colletotrichum siamense, Trial 4.

\begin{tabular}{cccc}
\hline Postharvest Treatments & $\begin{array}{c}\text { Anthracnose Lesion } \\
\text { Areas }\left(\mathbf{m m}^{\mathbf{2}}\right)\end{array}$ & $\begin{array}{c}\text { Days to Eating Ripe } \\
\text { Stage }\end{array}$ & Softness \\
\hline Control (water) & 5.7 & 13.0 & 1.3 \\
EO water $(20 \%$ v/v) & 1.3 & 12.9 & 1.5 \\
$\mathrm{NaOCl}\left(100 \mathrm{mg} \mathrm{L}^{-1}\right)$ & 4.1 & 13.0 & 1.5 \\
Graduate $\left(2.5 \mathrm{~mL} \mathrm{~L}^{-1}\right)$ & 0.0 & 13.1 & 1.5 \\
\hline
\end{tabular}

$n=4$ replicates of 5 fruit per replicate. $T$ indicates $\mathrm{mm}$ deformation upon $500 \mathrm{~g}$ weight applied on fruit for $30 \mathrm{~s}$.

Anthracnose and stem end rot arising from natural field infections were also assessed. Anthracnose incidence and severity were not significantly different amongst postharvest treatments (Table 7). However, the incidence $(p<0.05)$ and severity $(p<0.01)$ of stem end rot were significantly different (Table 7). Incidence of stem end rot in fruit from $20 \% v / v \mathrm{EO}$ water, $\mathrm{NaOCl}$, or Graduate $\mathrm{A}+$ treatments were similar and less than the fruit dipped in water, however, the difference was statistically significant only for $\mathrm{NaOCl}$ and Graduate A+ (Table 7). Severity of stem end rot in fruit dipped in EO water 20\% $v / v, \mathrm{NaOCl}$, and Graduate A+ was similar and was significantly less than in fruit dipped in water. Fruit firmness and time to reach eating ripe stage were not significantly affected by postharvest treatments (Table 7).

Table 7. Effect of electrolyzed oxidizing (EO) water, synthetic fungicide, and $\mathrm{NaOCl}$ on postharvest diseases and ripening properties of avocado (cv. Hass), Trial 4.

\begin{tabular}{ccccccc}
\hline \multirow{2}{*}{ Postharvest Treatments } & \multicolumn{2}{c}{ Anthracnose (\%) } & \multicolumn{2}{c}{ Stem End Rot (\%) } & $\begin{array}{c}\text { Days to Eating } \\
\text { Ripe Stage }\end{array}$ & Softness \\
\cline { 2 - 6 } & \multicolumn{2}{c}{ Incidence } & Severity & Incidence & Severity \\
\hline Control (water) & 100.0 & 78.5 & $80.0 \mathrm{a}$ & $32.7 \mathrm{a}$ & 12.9 & 1.5 \\
EO water $(20 \% \mathrm{v} / \mathrm{v})$ & 96.7 & 55.3 & $60.0 \mathrm{ab}$ & $8.3 \mathrm{~b}$ & 12.8 & 1.4 \\
$\mathrm{NaOCl}\left(100 \mathrm{mg} \mathrm{L}^{-1}\right)$ & 90.0 & 61.1 & $53.3 \mathrm{bc}$ & $15.9 \mathrm{~b}$ & 13.0 & 1.4 \\
Graduate A+ $\left(2.5 \mathrm{~mL} \mathrm{~L}^{-1}\right)$ & 83.3 & 58.8 & $23.3 \mathrm{dc}$ & $7.0 \mathrm{~b}$ & 13.0 & 1.4 \\
\hline
\end{tabular}

Within each column, means followed by the same letter do not differ significantly at the $5 \%$ level of probability according to LSD post hoc test. $n=4$ replicates of 10 fruit. $T$ indicates mm deformation upon $500 \mathrm{~g}$ weight applied on fruit for $30 \mathrm{~s}$.

\subsection{Trial 5}

This experiment was conducted under simulated commercial packing-line conditions. In previous trials, fruit were dipped for $30 \mathrm{~s}$; however, in this trial a $60 \mathrm{~s}$ treatment was included. The treatments were applied in an experimental sprayline at the Queensland Department of Agriculture and Fisheries' Maroochy Research Station, Nambour, Queensland.

Postharvest disease levels were very high in this late season Hass fruit. There were significantly $(p<0.05)$ fewer fruit sprayed with $20 \% v / v$ EO water or Graduate A+ for $30 \mathrm{~s}$ that had anthracnose, compared with fruit treated with water for $30 \mathrm{~s}$ (Table 8). EO water $(20 \% v / v)$ treatment for 30 or $60 \mathrm{~s}$, or Graduate A+ for $30 \mathrm{~s}$ significantly reduced anthracnose severity on fruit compared with the $30 \mathrm{~s}$ water control treatment (Table 8). Strikingly, EO water at both 30 and 60 s exhibited statistically similar reduction in severity of anthracnose as that of registered fungicide Graduate A+ under very high disease pressure.

Stem end rot incidence and severity were significantly affected $(p<0.01)$ by postharvest spray application of EO water and Graduate A+ (Table 8). Spraying with EO water $(20 \% v / v)$ for both 30 and $60 \mathrm{~s}$ had statistically identical numbers of fruit with SER as those treated with Graduate A+, which was significantly fewer than those from 30 or $60 \mathrm{~s}$ water treated controls. EO water $(20 \% v / v)$ and Graduate A+ 30 s spray significantly reduced SER severity as compared to those of water sprayed control fruit. 
Fruit from EO water $(20 \% v / v)$ for 30 or $60 \mathrm{~s}$ and Graduate A+ $30 \mathrm{~s}$ spray treatments had statistically similar SER severity. Fruit firmness and days to reach eating ripe stage were not significantly different among treatments (Table 8).

Table 8. Effects of electrolyzed oxidizing (EO) water and synthetic fungicide applied via simulated commercial packing line on postharvest diseases and ripening properties of avocado (cv. Hass), Trial 5.

\begin{tabular}{ccccccc}
\hline \multirow{2}{*}{ Postharvest Treatments } & \multicolumn{2}{c}{ Anthracnose (\%) } & \multicolumn{2}{c}{ Stem End Rot (\%) } & Days to & \multirow{2}{*}{ Softness } \\
\cline { 2 - 5 } & Incidence & Severity & Incidence & Severity & Eating Ripe & \\
\hline Control (water) $30 \mathrm{~s}$ & $97.0 \mathrm{a}$ & $62.1 \mathrm{a}$ & $52.0 \mathrm{a}$ & $8.22 \mathrm{ab}$ & 11.5 & 1.51 \\
Control (water) $60 \mathrm{~s}$ & $96.0 \mathrm{ab}$ & $57.2 \mathrm{ab}$ & $45.0 \mathrm{a}$ & $8.66 \mathrm{a}$ & 11.8 & 1.50 \\
EO water $(20 \% v / v) 30 \mathrm{~s}$ & $88.0 \mathrm{~b}$ & $40.6 \mathrm{~cd}$ & $27.0 \mathrm{~b}$ & $3.23 \mathrm{c}$ & 11.7 & 1.51 \\
EO water $(20 \% v / v) 60 \mathrm{~s}$ & $94.0 \mathrm{ab}$ & $50.1 \mathrm{bc}$ & $26.0 \mathrm{~b}$ & $4.52 \mathrm{bc}$ & 11.1 & 1.48 \\
Graduate A+ $\left(2.5 \mathrm{~mL} \mathrm{~L}^{-1}\right) 30 \mathrm{~s}$ & $91.0 \mathrm{~b}$ & $40.8 \mathrm{~cd}$ & $11.0 \mathrm{~b}$ & $0.96 \mathrm{c}$ & 11.8 & 1.50 \\
\hline
\end{tabular}

Within each column, means followed by the same letter do not differ significantly at the $5 \%$ level of probability according to LSD post hoc test. $n=5$ replicates of 20 fruit. $\uparrow$ indicates $\mathrm{mm}$ deformation upon $500 \mathrm{~g}$ weight applied on fruit for $30 \mathrm{~s}$.

\subsection{Measurement of Oxidation Reduction Potential (ORP), $p H$, and Free Chlorine in Treatment Solutions}

$\mathrm{ORP}, \mathrm{pH}$, and free chlorine $\left(\mathrm{OCl}^{-}\right)$of the treatment solutions used in Trials 2-5 were determined. ORP values for the EO water solutions $(20 \% v / v)$, hypochlorite, and control (tap) water were $795-906 \mathrm{mV}$, 733-767 mV, and 225-477 mV, respectively (Table 9). Where measured, hypochlorite solutions had the highest $\mathrm{pH}$, whereas the $\mathrm{pH}$ of $20 \% v / v$ EO water was more similar to that of water control. Free chlorine $\left(\mathrm{OCl}^{-}\right)$levels were found to be highest in the hypochlorite solution (0.15-0.16 ppm), with $0.09-0.10 \mathrm{ppm}$ in the EO water (20\% v/v) solutions (Table 9$)$.

Table 9. Chemical properties of treatment solutions.

\begin{tabular}{|c|c|c|c|}
\hline \multirow{2}{*}{ Treatment Solutions } & \multicolumn{3}{|c|}{ Chemical Properties of Treatment Solutions (Means \pm SEM) } \\
\hline & ORP (mV) & $\mathrm{pH}$ & $\mathrm{OCl}^{-}\left(\mathrm{mg} \mathrm{L}^{-1}\right)$ \\
\hline \multicolumn{4}{|l|}{ Trial 2} \\
\hline Control (water) & 225 & ND & ND \\
\hline EO water $(10 \% v / v)$ & 741 & ND & ND \\
\hline EO water $(20 \% v / v)$ & 795 & ND & ND \\
\hline EO water $(30 \% v / v)$ & 826 & ND & ND \\
\hline \multicolumn{4}{|l|}{ Trial 3} \\
\hline Control (water) & $310.7 \pm 2.85$ & $8.7 \pm 0.00$ & ND \\
\hline EO water $(20 \% v / v)$ & $906.3 \pm 1.20$ & $8.2 \pm 0.01$ & $0.09 \pm 0.013$ \\
\hline $\mathrm{NaOCl}\left(100 \mathrm{mg} \mathrm{L}^{-1}\right)$ & $767.0 \pm 0.58$ & $9.4 \pm 0.04$ & $0.16 \pm 0.007$ \\
\hline \multicolumn{4}{|l|}{ Trial 4} \\
\hline Control (water) & $477.0 \pm 2.86$ & $8.1 \pm 0.05$ & ND \\
\hline EO water $(20 \% v / v)$ & $863.0 \pm 1.00$ & $7.8 \pm 0.03$ & $0.10 \pm 0.007$ \\
\hline $\mathrm{NaOCl}\left(100 \mathrm{mg} \mathrm{L}^{-1}\right)$ & $733.7 \pm 1.76$ & $8.8 \pm 0.03$ & $0.15 \pm 0.004$ \\
\hline \multicolumn{4}{|l|}{ Trial 5} \\
\hline Control (water) & $331.7 \pm 0.33$ & $7.1 \pm 0.01$ & ND \\
\hline EO water $(20 \% v / v)$ & $852.7 \pm 0.33$ & $7.2 \pm 0.05$ & $0.15 \pm 0.004$ \\
\hline
\end{tabular}

\section{Discussion}

There was a consistent effect of electrolyzed oxidizing (EO) water and postharvest fungicide (Graduate $\mathrm{A}+$ ) in reducing postharvest diseases of avocado, particularly stem end rot, arising from natural field infections. In the case of natural infection, 5\%, 10\%, or 20\% $(v / v)$ EO water significantly reduced the severity of stem end rot disease compared to water-treated control fruit in all four trials where it was assessed. Control of SER was statistically similar to that achieved by Graduate A+, 
a fungicide registered in Australia for postharvest application for avocado since 2018 that is known to be particularly effective against stem end rot.

Fruit were sourced from orchards that had not been sprayed with copper fungicides throughout fruit development; consequently, anthracnose disease arising from natural field infections was extremely high in all four trials where it was assessed, with incidence (numbers of fruit) frequently at $80-90 \%$ with corresponding high severity (percent of surface area affected) at more than $50 \%$. Under such high disease pressure, EO water, bleach, as well as the fungicide treatments were ineffective, except in Trial 1 where both tested fungicides reduced severity, and Trial 5 where both $20 \%$ EO water and fungicide Graduate A+ applied under simulated commercial conditions reduced disease compared with water controls. A combination solution of EO water and fungicide was not included in the present study, but obviously further work should include this combination to assess whether there are additive effects, resulting in even greater reduction of postharvest disease in avocado.

A commercial bleach solution, sodium hypochlorite $(\mathrm{NaOCl})$, was assessed alongside $20 \% v / v$ EO water and fungicide Graduate A+ in two fruit dipping trials. There were no effects of any treatment on anthracnose, as discussed above. In one trial, reduction in stem end rot after $\mathrm{NaOCl}$ was not significantly different from water controls, and in the other trial, it reduced SER significantly compared with water but was still twice as severe as that in $20 \% v / v$ EO water and Graduate A+-treated fruit.

Anthracnose and stem end rot were significantly reduced due to application of EO water and Graduate A+ fungicide via an experimental packing line, simulating commercial practice. Overhead spray treatment while fruit were rotated on brushes for 30 or $60 \mathrm{~s}$ in EO water solution or Graduate A+ had statistically similar impacts on reduction of postharvest diseases.

Although this is the first report demonstrating efficacy of EO water to reduce postharvest diseases in avocado, there are a few reports on other fresh produce that support the findings of the present research. Effects of surface disinfectants (chlorinated water at $100 \mathrm{mg} \mathrm{kg}^{-1}$, EO water of $\mathrm{pH} 6-7$, hot water at $53{ }^{\circ} \mathrm{C}$ for $20 \mathrm{~s}$, and biocontrol agent, namely, B13 yeast, a strain of Candida fermentati) were evaluated for effects on postharvest quality of kumquat citrus (Fortunella sp.) [30]. Fruit treated with a combination of EO water, hot water, and biocontrol agent displayed no visible growth of mold fungi during the 28 day storage period. However, chlorinated water $\left(100 \mathrm{mg} \mathrm{kg}^{-1}\right.$; $\mathrm{pH}$ of 7.0-7.2) alone produced the highest decay $(13.6 \%)$, whereas fruit subjected to EO water only displayed significantly reduced level of decay $(4.08 \%)$ as compared to chlorinated water by 28 days, suggesting potential of enhanced efficacy from combined applications of the control agents. The study concluded that integration of EO water, hot water, and biocontrol was among the most effective treatments in maintaining quality of kumquat fruit. In another study, EO water was also tested on date (Phoenix dactylifera) to improve shelf life and quality by reducing microbial population [31,32]. Dates were dipped in EO water solutions ( $\mathrm{pH} 7-7.5$; ORP $800-850 \mathrm{mV}$ ) at three concentrations $(1 \%, 3 \%$, and $5 \%$ ) and for various durations ( 0 to $4 \mathrm{~min}$ ). Total counts of mesophilic bacteria was reduced by up to $99.5 \%$ and yeast and molds were completely eliminated.

In the present study, lesions arising from inoculation of harvested avocado fruit with the anthracnose pathogen, Colletotrichum siamense, were significantly smaller in two of the three trials where assessed, with indications of reduction in the third trial. This indicates a protective effect of EO water application, and suggests that sprays in the field during fruit development may contribute to lower disease and improved quality through the supply chain. A study conducted by Guentzel, Callan, Liang Lam, Emmons, and Dunham [24] reported that EO water of near neutral pH (6.3-6.5) was found to be effective to manage infection of Botrytis cinerea on strawberry plants in the field and also as a disinfection solution for harvesting equipment, greenhouses, packing houses, and in commercial facilities to prevent or limit infections of B. cinerea and Monilinia fructicola. Application of $100 \mathrm{ppm}$ EO water twice per week to strawberry plants infected with $B$. cinerea was more effective than a once per week fungicide (Captan) application [24]. Fujiwara, Fujii, and Park [25] reported that the severity of powdery mildew infection and phytotoxic symptoms on cucumber leaves sprayed successively with $\mathrm{EO}$ and electrolyzed reducing water were reduced compared with $\mathrm{EO}$ sprays only. An in vitro 
assessment showed that germination of 22 test fungi was significantly reduced or prevented by EO water [33]. All relatively thin-walled species (e.g., Botrytis sp., Monilinia sp.) were killed by incubation times of $30 \mathrm{~s}$ or less. Thicker-walled, pigmented fungi (e.g., Curvularia sp., Helminthosporium sp.) required $2 \mathrm{~min}$ or longer for germination to be reduced significantly [33]. There is likely to be a direct inhibitory effect of EO water on avocado fungal pathogens, and this will be confirmed in future work.

Firmness and shelf life are important postharvest quality parameters for fresh fruit and vegetables, and may determine market destination. In the present study, postharvest treatments mostly had no significant effects on number of days to ripen and firmness, measured by instrumentation. In two trials, Graduate A+ fungicide-treated fruit was significantly less firm than fruit in all other treatments, with the exception of Sportak in the first trial. Treated fruit took significantly longer (approximately 1-2.5 days) to ripen than water-treated fruit in one trial where fruit was inoculated with $C$. siamense. A similar finding was also reported by Workneh et al. [34], who demonstrated that disinfecting treatments (EO water and chlorinated water) had no significant effects on firmness, total soluble solid content, and the overall visual appearance of carrots. Sensory assessment showed no significant difference related to taste, odor, texture, and color of treated dates [32]. Recent biochemical studies in blueberries reported that EO water treatment delayed softening of blueberries, most likely through deactivation of cell wall-degrading enzymes [35] and regulation of reactive oxygen species [36], maintaining cellular integrity for a longer period compared with untreated fruit. Although there were no visible effects of EO water on harvested avocado fruit in the current study, future field or postharvest applications to foliage, fruit, or roots should be carefully monitored for any phytotoxic damage that could reduce yields or negatively impact quality.

Apart from ORP, the antimicrobial properties of available chlorine species hypochlorous acid $(\mathrm{HOCl})$ and hypochlorite ions $\left(\mathrm{OCl}^{-}\right)$in EO water may also contribute to the reduction of postharvest diseases of avocado in the current study. Free chlorine is the sum of hypochlorous acid and hypochlorite $\left(\mathrm{HOCl}+\mathrm{OCl}^{-}\right)$that plays a vital role in the disinfection processes [15]. Chlorine causes direct damage to cell membrane of microorganisms, making them permeable, resulting in cell inactivation due to damage of the key organelles by the chlorine [15]. Gray [15] reported that for chlorination to be effective against bacteria and viruses, water should have a $\mathrm{pH}<8.0$ with a chlorine dose sufficient to produce a free chlorine residual of $0.5 \mathrm{mg} \mathrm{L}^{-1}$ over a contact time of $30 \mathrm{~min}$. For inactivation of $E$. coli free chlorine concentration of $0.03 \mathrm{mg} \mathrm{L}^{-1}$ per min is required at $25^{\circ} \mathrm{C}$ [15]. For E coli O157H7, Salmonella typhi, and Shigella sonnei, the free chlorine concentrations required per min for inactivation were $0.1 \mathrm{mg} \mathrm{L}^{-1}$ at $21^{\circ} \mathrm{C}, 0.5 \mathrm{mg} \mathrm{L}^{-1}$ at $25^{\circ} \mathrm{C}$, and $0.5 \mathrm{mg} \mathrm{L}^{-1}$ at $25^{\circ} \mathrm{C}$ [15], respectively. These findings were in support of the results of the present investigation where the free chlorine (hypochlorite ions) levels of the EO water solutions ranged from 0.1 to $0.2 \mathrm{mg} \mathrm{L}^{-1}$.

The concentration of $\mathrm{HOCl}$ was not determined directly in the current study, however, both $\mathrm{HOCl}$ and $\mathrm{OCl}^{-}$have disinfection properties. The degree of dissociation of $\mathrm{HOCl}$ is $\mathrm{pH}$-dependent and gradually decreases as the $\mathrm{pH}$ falls; for example, at $\mathrm{pH}<5.0$, approximately $100 \%$ of the chlorine is in $\mathrm{HOCl}$ form, which falls to $50 \%$ at $\mathrm{pH} 7.5$, whereas at $\mathrm{pH}>9.0,100 \%$ of chlorine is present as $\mathrm{OCl}^{-}$. $\mathrm{EO}$ water generally exerts its maximum effects at neutral $\mathrm{pH}[7,9,32]$ and with ORP of more than $850 \mathrm{mV}$ [16]. In the present study, the $\mathrm{pH}$ of $20 \% v / v$ EO water solutions were 7.2 to 8.2 , and ORP 795-906 mV, compared with hypochlorite bleach solutions (two trials) which had higher $\mathrm{pH}$ of 8.8-9.4 and lower ORP of 734-767 mV. Neutral $\mathrm{pH}$ and the possible higher activity of $\mathrm{HOCl}$ in the case of Trial 5 (experimental packing line) may have contributed to the significantly reduced severity of both natural anthracnose and stem end rot diseases. By contrast, higher $\mathrm{pH}$ and lower ORP of the sodium hypochlorite solutions resulted in higher levels of infections that were statistically identical to control fruit despite having similar or higher concentration of $\mathrm{OCl}^{-}$species.

Although not determined in the current study, it is likely that EO water would reduce foodborne (human) bacterial pathogens such as Salmonella spp., Listeria monocytogenes, and Escherichia coli on avocado fruit surfaces and in processed pulp products. A recent survey by the United States Food and Drug Administration reported a high incidence (18\%) of Listeria sp. detected on avocado skin 
samples, with equal numbers from domestic versus imported sources testing positive [37]. There was a lower incidence (3.3\%) of Salmonella spp. detected. Similar low levels (2.3\%) of Listeria was present in processed avocado or guacamole product, where most of the tested samples were of U.S. origin. Another study in South Africa reported a high incidence (14\%) of E. coli, $2.4 \%$ of Salmonella sp., and no Listeria sp. from skin and pulp samples [38].

EO water has been approved by regulatory authorities for use as a sanitizer in the food industry. It has been approved for the use in organic production by the United States Department of Agriculture (USDA) in 2015 through a USDA memorandum [39] updating the status of electrolyzed water under USDA Organic Regulations. In the United States, it is also approved by the Food and Drug Administration (FDA) for cleaning and sanitizing purposes [9,32]. EO water is also used in hospitals, food facilities, and agricultural venues in the European Union as disinfectant [31,32]. In Australia, e-Waters Systems has recently (August 2018) received HACCP certification (the international standard defining the requirements for effective control of food safety), for their two models of generators of food-safe cleaning and sanitizing liquids, known as EO water, suitable for use in food facilities and food handling operations [40].

\section{Conclusions}

Electrolyzed oxidizing (EO) water has mostly been studied and adopted from the food safety and control of food-borne pathogens standpoint. Hence, reports on the effectiveness of EO water on the suppression of plant pathogens and the diseases they cause in fruit and vegetables are limited. There is scope for including EO water in integrated postharvest disease management of avocado, as these results suggest the potential to use EO water as a protectant to reduce field infections as well as reducing disease caused by those latent infections during storage and ripening processes. Further evaluation in avocado is required to determine efficacy of EO water to eradicate harmful human foodborne bacteria, and as part of existing fruit rot management strategies including complementary treatments with traditional fungicides. Conceivably, an initial wash with EO water followed by fungicide treatment could be easily integrated into fresh fruit packing facilities.

Author Contributions: Conceptualization, project administration, funding acquisition, E.D.; methodology, E.D. and M.K.H.; investigation, formal analysis, data curation, writing—original draft preparation, M.K.H.; resources, writing-review and editing, E.D. and M.K.H.

Funding: AV16007 is funded by Hort Innovation, using the avocado research and development levy and contributions from the Australian Government. Hort Innovation is the grower-owned, not-for-profit research and development corporation for Australian horticulture. The project is jointly supported by the Department of Agriculture and Fisheries and the University of Queensland. The authors wish to acknowledge the financial support received from Department of Education and Training Australia (Endeavour Research Fellowship to M. K. Hassan) to conduct the study.

Acknowledgments: The authors acknowledge useful interactions and support received from Roger Stanley (University of Tasmania), Keith Mason (EnviroLyte Asia Pacific), Mark Parkinson (Lockyer Agronomics Pty. Ltd.), Anderson Horticulture, Pty. Ltd., and Akila Prabhakaran (The University of Queensland) during the course of study.

Conflicts of Interest: The authors declare no conflict of interest. The funders had no role in the design of the study; in the collection, analyses, or interpretation of data; in the writing of the manuscript, or in the decision to publish the results.

\section{References}

1. Dann, E.K.; Ploetz, R.C.; Coates, L.M.; Pegg, K.G. Foliar, fruit and soilborne diseases. In The Avocado: Botany, Production and Uses, 2nd ed.; Schaffer, B., Wolstenholme, N., Whiley, A., Eds.; CABI Publishing: Wallingford, UK, 2013; pp. 380-422.

2. Hartill, W.F.T. Post-harvest diseases of avocado fruits in New Zealand. N. Z. J. Crop. Hortic. Sci. 1991, 19, 297-304. [CrossRef]

3. Darvas, J.M. The control of postharvest avocado diseases with prochloraz. S. Afr. Avocado Grow. Assoc. Yearb. 1984, 7, 57-58. 
4. Smith, L.A.; Dann, E.K.; Leonardi, J.; Dean, J.R.; Cooke, A.W. Exploring non-traditional products for management of postharvest anthracnose and stem end rot in avocado. In Proceedings of the 7th World Avocado Congress, Cairns, Australia, 5-9 September 2011; pp. 215-221.

5. Dewi, F.R.; Stanley, R.; Powell, S.M.; Burke, C.M. Application of electrolysed oxidising water as a sanitiser to extend the shelf-life of seafood products: A review. J. Food Sci Technol 2017, 54, 1321-1332. [CrossRef] [PubMed]

6. Hricova, D.; Stephan, R.; Zweifel, C. Electrolyzed water and its application in the food industry. J. Food Prot. 2008, 71, 1934-1947. [CrossRef] [PubMed]

7. Fukuzaki, S. Mechanisms of actions of sodium hypochlorite in cleaning and disinfection processes. Biocontrol Sci. 2006, 11, 147-157. [CrossRef] [PubMed]

8. Powitz, R.W. Activated and electrolysed water: A brief review of a new generation of cleaners and sanitizing agents. In Food Safety Magazine; Stacy Atchison (Publisher): Glendale, CA, USA, 2010.

9. Rahman, S.M.E.; Khan, I.; Oh, D.-H. Electrolyzed water as a novel sanitizer in the food industry: Current trends and future perspectives. Compr. Rev. Food Sci. Food Saf. 2016, 15, 471-490. [CrossRef]

10. Al-Haq, M.I.; Sugiyama, J.; Isobe, S. Applications of electrolyzed water in agriculture and food industries. Food Sci. Technol. Res. 2005, 11, 135-150. [CrossRef]

11. Deza, M.A.; Araujo, M.; Garrido, M.J. Efficacy of neutral electrolyzed water to inactivate Escherichia coli, Listeria monocytogenes, Pseudomonas aeruginosa, and Staphylococcus aureus on plastic and wooden kitchen cutting boards. J. Food Prot. 2007, 70, 102-108. [CrossRef] [PubMed]

12. Kim, C.; Hung, Y.C.; Brackett, R.E. Roles of oxidation-reduction potential in electrolyzed oxidizing and chemically modified water for the inactivation of food-related pathogens. J. Food Prot. 2000, 63, 19-24. [CrossRef] [PubMed]

13. Len, S.V.; Hung, Y.C.; Erickson, M.; Kim, C. Ultraviolet spectrophotometric characterization and bactericidal properties of electrolyzed oxidizing water as influenced by amperage and pH. J. Food Prot. 2000, 63, 1534-1537. [CrossRef] [PubMed]

14. Len, S.V.; Hung, Y.C.; Chung, D.; Anderson, J.L.; Erickson, M.C.; Morita, K. Effects of storage conditions and $\mathrm{pH}$ on chlorine loss in electrolyzed oxidizing (EO) water. J. Agric. Food Chem. 2002, 50, 209-212. [CrossRef] [PubMed]

15. Gray, N.F. Free and combined chlorine. In Microbiology of Waterborne Diseases: Microbiological Aspects and Risks, 2nd ed.; Percival, S.L., Yates, M.V., Williams, D.W., Chalmers, R.M., Gray, N.F., Eds.; Elsevier Ltd. (Academic Press): Oxford, UK, 2014; pp. 571-590.

16. Jay, J.M.; Loessner, M.J.; Golden, D.A. Modern Food Microbiology, 7th ed.; Springer: New York, NY, USA, 2005.

17. Suslow, T.V. Oxidation-Reduction Potential (ORP) for Water Disinfection Monitoring, Control, and Documentation; ANR Publication No. 8149; University of California Davis: Oakland, CA, USA, 2004; pp. 1-5. [CrossRef]

18. Wholey, W.Y.C. Hypochlorous Acid Stress Responses in Bacteria; The University of Michigan: Ann Arbor, MI, USA, 2012.

19. Copeland, A.; Lytle, D.A. Measuring the oxidation-reduction potential of important oxidants in drinking water. J. Am. Water Work. Assoc. 2014, 106, E10-E20. [CrossRef]

20. Cao, W.; Zhu, Z.W.; Shi, Z.X.; Wang, C.Y.; Li, B.M. Efficiency of slightly acidic electrolyzed water for inactivation of Salmonella enteritidis and its contaminated shell eggs. Int. J. Food Microbiol. 2009, 130, 88-93. [CrossRef] [PubMed]

21. Huang, Y.-R.; Hung, Y.-C.; Hsu, S.-Y.; Huang, Y.-W.; Hwang, D.-F. Application of electrolyzed water in the food industry. Food Control 2008, 19, 329-345. [CrossRef]

22. Rajeshwar, K.; Ibanez, J.G. Environmental Electrochemistry: Fundamentals and Applications in Pollution Sensors and Abatement; Academic Press Inc.: San Diego, CA, USA, 1997; p. 776.

23. Boshoff, M.; Slabbert, M.J.; Korsten, L. Effect of detergent sanitizers on post-harvest diseases of avocado. S. Afr. Avocado Grow. Assoc. Yearb. 1995, 18, 96-98.

24. Guentzel, J.L.; Callan, M.A.; Liang Lam, K.; Emmons, S.A.; Dunham, V.L. Evaluation of electrolyzed oxidizing water for phytotoxic effects and pre-harvest management of gray mold disease on strawberry plants. Crop. Prot. 2011, 30, 1274-1279. [CrossRef]

25. Fujiwara, K.; Fujii, T.; Park, J.S. Successive spraying efficacy of acidic electrolyzed oxidizing water and alkalic electrolyzed reducing water on controlling powdery mildew infection and suppressing visible physiological disorder on cucumber leaves. Hortic. Environ. Biotechnol. 2011, 52, 387-392. [CrossRef] 
26. Envirolyte®. Disinfection, sterilization and water purification. Available online: http://www.envirolyte.com (accessed on 23 July 2019).

27. Ayebah, B.; Hung, Y.-C. Electrolyzed water and its corrosiveness on various surface materials commonly found in food processing facilities. J. Food Process. Eng. 2005, 28, 247-264. [CrossRef]

28. Walker, S.P.; Demirci, A.; Graves, R.E.; Spencer, S.B.; Roberts, R.F. Response surface modelling for cleaning and disinfecting materials used in milking systems with electrolysed oxidizing water. Int. J. Dairy Technol. 2005, 58, 65-73. [CrossRef]

29. Macnish, A.J.; Joyce, D.C.; Shorter, A.J. A simple non-destructive method for laboratory calculation of firmness. Aust. J. Exp. Agric. 1997, 37, 709-713. [CrossRef]

30. Kassim, A.; Workneh, T.S.; Laing, M.D.; Basdew, I.H. The effects of different pre-packaging treatments on the quality of kumquat fruit. CyTA J. Food 2016, 14, 639-648. [CrossRef]

31. Bessi, H.; Debbabi, H.; Grissa, K.; Bellagha, S. Microbial reduction and quality of stored date fruits treated by electrolyzed water. J. Food Qual. 2014, 37, 42-49. [CrossRef]

32. Bessi, H.; Debbabi, H.; Grissa, K.; Bellagha, S. Effect of electrolysed water (anolyte) dipping on microbial, physicochemical and sensorial quality of date fruit. Acta Hortic. 2012, 934, 683-688. [CrossRef]

33. Buck, J.W.; van Iersel, M.W.; Oetting, R.D.; Hung, Y.-C. In vitro fungicidal activity of acidic electrolyzed oxidizing water. Plant Dis. 2002, 86, 278-281. [CrossRef] [PubMed]

34. Workneh, T.S.; Osthoff, G.; Pretorius, J.C.; Hugo, C.J. Comparison of anolyte and chlorinated water as a disinfecting dipping treatment for stored carrots. J. Food Qual. 2003, 26, 463-474. [CrossRef]

35. Chen, Y.; Hung, Y.-C.; Chen, M.; Lin, H. Effects of acidic electrolyzed oxidizing water on retarding cell wall degradation and delaying softening of blueberries during postharvest storage. LWT Food Sci. Technol. 2017, 84, 650-657. [CrossRef]

36. Chen, Y.; Hung, Y.-C.; Chen, M.; Lin, M.; Lin, H. Enhanced storability of blueberries by acidic electrolyzed oxidizing water application may be mediated by regulating ROS metabolism. Food Chem. 2019, 270, 229-235. [CrossRef] [PubMed]

37. FDA, U.S. Food and Drug Administration. Microbiological Surveillance Sampling: FY14-16 Whole Fresh Avocados (Report); FDA, U.S. Food and Drug Administration: Silver Spring, MD, USA, 2018; Volume 2019.

38. Coetzee, C.; du Plessis, E.; Duvenage, S.; Korsten, L. Bacterial dynamics and the prevalence of foodborne pathogens associated with avocado fruit Persea americana Mill. S. Afr. Avocado Grow. Assoc. Yearb. 2017, 40, 36-40.

39. McEvoy, M.V. Policy Memorandum 15-4 Electrolyzed Water United States Department of Agriculture; AUSDA: Washington, DC, USA, 2015; p. 2.

40. eWatersystems. HACCP Certification: Certificate Number PE-887-EWT-01. Available online: https://www. ewatersystems.com/haccpcertificate (accessed on 26 February 2019). 